\title{
Påvisning av nye biomarkører i plasma-proteomet
}

\author{
Jens P. Berg ${ }^{1,2}$, John Henninge ${ }^{1}$ og Terje Lund ${ }^{1}$ \\ 1) Hormonlaboratoriet, Aker universitetssykehus, Oslo \\ 2) Universitetet i Oslo, Oslo \\ Korrespondanse: Jens P. Berg, Hormonlaboratoriet, Aker universitetssykehus, 0514 Oslo \\ E-post: j.p.berg@medisin.uio.no Telefon: 22894358
}

\begin{abstract}
SAMMENDRAG
Svar på laboratorieanalyser er av avgjørende betydning for ressursbruk i helsevesenet $\mathrm{i}$ forbindelse med utredning, behandling og oppfølgning av pasienter. Undersøkelser fra USA viser at ca. $70 \%$ av alle beslutninger som foretas i helsevesenet i stor grad er basert på resultater fra laboratoriene (1). Størst betydning for bruk av ressurser og folkehelse har laboratorieanalyser som kan brukes til å identifisere personer med økt risiko for sykdom som kan forebygges eller kureres. De mest dramatiske eksempler på dette finner man for noen dominant arvelige kreftformer hvor en enkelt genetisk undersøkelse kan påvise personer som trenger ekstra oppfølgning og i enkelte tilfeller profylaktisk kirurgisk behandling.

Blod utgjør det viktigste materialet for laboratorieundersøkelser. I denne artikkelen vil vi beskrive noen av mulighetene som finnes i letingen etter nye biomarkører i form av proteiner og peptider i plasmaproteomet som betegner det totale uttrykket av proteiner i plasma. Utviklingen av immunometriske og massespektrometriske metoder har åpnet nye muligheter til å finne nye sykdomsmarkører både som "nye" proteiner og i form av modifikasjoner som er dannet etter at proteinet er syntetisert (post-translasjonelle modifikasjoner). Effektiv testing av kombinasjoner av flere titalls markører gjør det mulig å lete etter sykdomsspesifikke "fingeravtrykk" i proteomet. Plasma-proteomet karakteriseres imidlertid også av at bare noen få proteiner utgjør kvantitativt det meste av proteomet og av store konsentrasjonsforskjeller mellom de ulike proteinene. God tilgang på godt karakteriserte kliniske materialer er helt nødvendig for å kunne validere nytten av en ny biomarkør. Et effektivt samarbeid mellom metode-utviklere og biobanker er derfor av avgjørende betydning for hvor raskt en ny biomarkør kan bli en diagnostisk eller prognostisk faktor.
\end{abstract}

\section{Berg JP, Henninge J, Lund T. Determination of new biomarkers in the plasma proteome. Nor J Epidemiol 2006; 16 (1): 35-40.}

\section{ENGLISH SUMMARY}

Decision making and use of health care resources depend to a large extent on data from in vitro diagnostic procedures. Laboratory results may have its largest impact on diseases that can be prevented or cured. Most dramatically a single genetic analysis can in certain dominantly inherited diseases differentiate between subjects who are at high risk of developing cancer and subjects who have a risk comparable to the general population. Ultimately, the test may identify individuals eligible for curative prophylactic surgery.

Blood is the most important specimen for laboratory investigations. This paper describes some of the possibilities that are emerging in the search for new protein and peptide biomarkers in the plasma proteome, which is the total expression of proteins in plasma. The development of new immunometric and mass spectrometric methods has opened new strategies to identify disease markers both as novel proteins and differences in their post-translational modifications. Efficient testing of combinations of tens of markers simultaneously makes it technically possible to search for fingerprints of specific diseases in the proteome. However, a few plasma proteins dominate quantitatively and there are huge concentration differences among the proteins. Access to well characterized clinical samples is of great importance for the validation of new candidate markers. Close cooperation between biomarker hunters and serum or plasma biobanks is a crucial determinant for the transition of a biomarker candidate to a potential diagnostic of prognostic factor.

\section{INNLEDNING}

Blod består av ca. $45 \%$ blodceller og $55 \%$ plasma. Plasma er en svært komplekst sammensatt væske og inneholder typisk ca. $92 \%$ vann, $6-8 \%$ proteiner, $0,8 \%$ salter, $0,6 \%$ lipider, $0,1 \%$ glukose og andre karbohyd- rater samt små mengder av andre stoffer som aminosyrer og vitaminer. Sammensetningen og uttrykket av proteiner i plasma betegnes gjerne plasma-proteomet (2). Serum dannes ved å la blodprøven koagulere, men det er større forskjeller mellom plasma- og serumproteomet enn et simpelt fravær av koagulasjonsfakto- 
rer i det sistnevnte (3). En tilsvarende betegnelse for de småmolekylære substansene er plasma-metabolomet (4).

Det humane plasma-proteomet inneholder trolig de aller fleste kjente humane proteiner i tillegg til at det ved sykdommer kan inneholde proteiner fra virus, bakterier og sopp. Proteinene kan grupperes etter funksjon eller opprinnelse (tabell 1) (2). Proteiner som albumin og immunglobuliner finnes i høye konsentrasjoner, mens det er svært lave nivåer av proteiner som skyldes lekkasje fra celler (figur 1). Ett gen kan gi opphav til mange forskjellige genprodukter samtidig som modifikasjoner av proteinet etter at det er syntetisert (posttranslasjonelle modifikasjoner) ytterligere øker variabiliteten av proteomet (5). Et anslag er at det finnes ca. 500 "ekte" plasmaproteiner (den første gruppen i tabell 1). Hvert av disse kan anslagsvis ha fem forskjellige former (forstadium, isoformer, nedbrytningsprodukter) i kombinasjon med 20 forskjellige post-translasjonelle modifikasjoner. Det betyr at denne delen alene av plasma-proteomet kan utgjøre så mye som 50.000 forskjellige molekylære former (2). Den mest ekstreme variasjonen finnes blant immunglobulinene som hos en voksen trolig består av 10 millioner forskjellige sekvenser. Kompleksiteten i proteomet er mange ganger høyere enn den man finner i genomet. Det er spesielt viktig å ta hensyn til dette ved studier av proteomet siden de analyseinstrumentene som brukes ofte ikke er i stand til å skille mellom alle variantene og gir et svært forenklet bilde.

Et forsøk på å lage en liste over antall proteiner $\mathrm{i}$ plasma-proteomet med utgangspunkt $i$ en kombinasjon av litteratursøk og tre forskjellige proteinanalysemetoder endte med 1175 distinkte genprodukter (6). Det høye tallet på komponenter og det enormt store spennet i konsentrasjonsnivåer gjør plasma-proteomet til det vanskeligste proteomet å undersøke, men det har også de største diagnostiske mulighetene. Nesten alle kroppens celler er i nær kommunikasjon med plasma og kan frigjøre sitt innhold i det ved skade eller sykdom. Hjerteinfarkt diagnostiseres per definisjon på basis av lekkasje og påfølgende karakteristiske endringer i serum- eller plasma-konsentrasjonene av hjertemarkørene troponin I eller T (7). Tilsvarende spesifikke markører for sykdom $\mathrm{i}$ andre organer er under utvikling.

\section{METODER FOR Å UNDERSØKE PLASMA- PROTEOMET}

\section{Enzymaktivitet}

Enzymaktivitetsmålinger i plasma var de første analysene som ble automatisert innen klinisk kjemi (8). Analysene er enkle, billige og krever ingen forbehandling $\mathrm{i}$ form av fraksjonering eller isolering av enzymene. Økningen i aktiviteten til alkaliske og sure fosfataser er forbundet med sykdom i henholdsvis ben og prostata. Men utsagnskraften ved enzymaktivitetsmålinger er begrenset ved at de kun gir et mål på funksjon og ingen informasjon om spesifikk kilde til proteinet eller isoformer av det hvis det ikke på forhånd gjøres en fraksjonering.

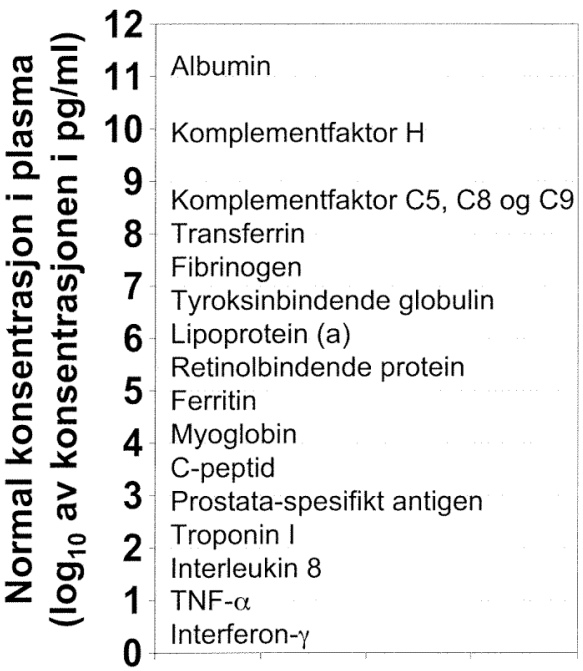

Figur 1. Eksempler på noen plasma-proteiner og de store konsentrasjonsforskjellene mellom dem. Proteinkonsentrasjonen av albumin er ca. 100 milliarder ganger høyere enn konsentrasjonen av interferon- $\square$

Tabell 1. Gruppering av plasmaproteiner etter funksjon.

\begin{tabular}{|c|c|c|}
\hline Gruppe & Karakteristikk & Eksempel \\
\hline $\begin{array}{l}\text { Lages i solide organer og har } \\
\text { sin funksjon i plasma }\end{array}$ & $\begin{array}{l}\text { Molekylvekt større enn filtrasjonsgrensen i nyrene (ca. } 45 \\
\mathrm{kDa} \text { ) }\end{array}$ & Albumin \\
\hline Immunglobuliner & $\begin{array}{l}\text { Ekstrem kompleksitet (antagelig } 10 \text { millioner forskjellige } \\
\text { sekvenser) }\end{array}$ & \\
\hline Langtvirkende reseptor-ligander & Peptid- og proteinhormoner & Insulin \\
\hline Lokale reseptor-ligander & Vekstfaktorer og inflammasjonsmediatorer & Interleukiner \\
\hline "Midlertidige passasjerer" & Skilles ut i ett organ for å bli tatt opp i et annet & Lysosomale proteiner \\
\hline Produkter fra vevslekkasje & $\begin{array}{l}\text { Virker normalt intracellulært, men kan frigjøres ved } \\
\text { vevsskade }\end{array}$ & $\begin{array}{l}\text { Kardiale troponiner } \\
\text { Kreatin kinase }\end{array}$ \\
\hline Aberrante sekresjoner & Sekresjon av proteiner fra svulster eller annet sykt vev & Cancer-markører \\
\hline Fremmedproteiner & Proteiner fra infeksiøse organismer eller parasitter & \\
\hline
\end{tabular}




\section{Antistoffbaserte analyser}

Alle proteiner har unike overflater som er i stand til å utløse en immunreaksjon. Hvis man har tilgang til renset protein til immunisering av et dyr, kan det samles polyklonale antistoff som igjen kan brukes til å lage immunokjemiske tester for spesifikk kvantitering av proteinet. I fremstillingen av monoklonale antistoff er kravet til rensing av proteinet mindre og dyret kan immuniseres med blandinger av antigener. De forskjellige klonene som dannes screenes deretter for å finne det antistoffet som er best $\mathrm{i}$ stand til å skille mellom prøve fra frisk eller syk. Antistoffbaserte metoder er uovertrufne til å påvise "fremmede" proteiner som lekker ut i sirkulasjonen fra sykt vev. For eksempel er det thyreoidea-spesifikke proteinet tyreoglobulin serummarkør i oppfølgningen av pasienter som er behandlet for kreft i thyreoidea (9). Tyreoglobulin og andre kreft-markører finnes normalt $\mathrm{i}$ svært lave konsentrasjoner i plasma, og er dermed gode immunogener.

Antistoffbaserte mikromatriser er en variant av immunoassayet (10). Basis for mikromatrisen er som regel et objektglass som er forbehandlet slik at for eksempel antistoffer kan festes til det. Proteiner som kan kvantiteres ved hjelp av et såkalt sandwich-assay, kan i prinsippet analyseres ved hjelp av mikromatrise. Som eksempel kan det bygges opp ved at mikroskopiske felt med forskjellige monoklonale antistoffer fra mus rettet mot proteinene som skal undersøkes, appliseres som punkter på objektglasset etter et bestemt mønster (matrise). Glasset med antistoffene inkuberes med prøven, vaskes og inkuberes deretter med sekundære polyklonale antistoffer fra for eksempel kanin. De må være rettet mot en annen epitop enn "capture"antistoffet på objektglasset. Deretter kvantiteres bindingen av det sekundære antistoffet ved hjelp av et fluorescensmerket tredje antistoff som gjenkjenner og binder seg til antistoff fra kanin. Fluorescensen avleses i en skanner og intensiteten er uttrykk for mengden av proteinet i prøven. Ved å bruke en variant av denne metoden ble det kvantitert 75 forskjellige cytokiner samtidig med sensitivitet fra 1-1000 pg/ml (11).

\section{To-dimensjonal elektroforese}

To-dimensjonal elektroforese ble tatt i bruk for over 30 år siden, men har nå fått en renessanse $(12,13)$. Dette skyldes hovedsakelig at det har blitt betydelig enklere å påvise identiteten til proteinene i gelen. Økte kunnskaper om genomets sammensetning har ført til at man kan predikere hvilke proteiner proteomet består av og hvilke peptider som dannes og påvises ved proteasebehandling og massespektrometriske metoder (se MALDI-TOF-MS). Proteinene $i$ en serum- eller plasma-prøve kan separeres både ved hjelp av deres isoelektriske punkt (pI) og masse. Ved to-dimensjonal gelelektroforese separeres først proteinene på en gelstripe med en pH-gradient. Når det settes et elektrisk felt på stripen, vil proteinene vandre i gelen til det $\mathrm{pH}$ - punkt hvor proteinet har null netto ladning, det vil si det isoelektriske punkt (pI). Deretter plasseres gelstripen med proteiner på en SDS-polyakrylamidgel. I et elektrisk felt blir proteinene så separert etter molekylmassen idet de små proteinene vandrer hurtigere $i$ gelen enn de store. Den to-dimensjonale elektroforesen skiller proteinene etter pI i X-aksen og masse i Yaksen (figur 2). Dersom man ønsker å identifisere spesifikke proteiner eller modifikasjoner av proteinene, kan gelen blottes over til en membran og inkuberes med antistoffer rettet mot det proteinet eller den strukturen man ønsker å visualisere. To-dimensjonal gelelektroforese krever stor grad av metodeutvikling for å få så reproduserbare resultater som mulig. Det er også en relativt tid- og arbeidskrevende metode siden hver enkelt prøve krever sin egen gel. Dette stiller ekstra store krav til reproduserbarhet idet man ønsker å sammenligne resultatene fra flere prøver med hverandre. På internettsiden til Swiss Institute of Bioinformatics er det eksempler på to-dimensjonale gelelektroforeser av plasma og hvilke proteiner som er identifisert (http://www.expasy.org/cgi-bin/map2/def?PLASMA HUMAN). Den store mengden av noen få plasmaproteiner gjør det vanskelig å detektere proteiner som forekommer i lave konsentrasjoner (figur 3). Proteiner som albumin, transferrin og immunglobuliner kan imidlertid fjernes fra prøven ved en forbehandling slik at analysen av proteiner som finnes i lav konsentrasjon forbedres $(14,15)$. Prøvene kan også forbehandles kromatografisk for å fjerne eller konsentrere proteiner med bestemte egenskaper før elektroforesen. For å identifisere proteinene som separeres ved hjelp av elektroforesen, benyttes det massespektrometriske metoder.

$\mathrm{pl} 3$ pl10

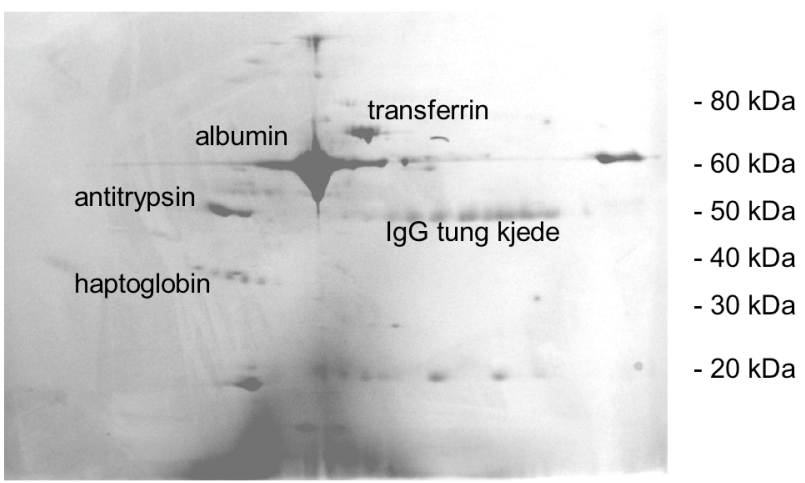

Figur 2. Separasjon av serum-proteiner ved hjelp av todimensjonal elektroforese (pI-gradient 3-10) og farging med Coomassie Brilliant Blue viser at noen få proteiner dominerer kvantitativt. Spredningen av et protein med samme molekylvekt over et stort pI-område kan være uttrykk for både genetiske varianter og post-translasjonelle modifikasjoner av proteinet. 


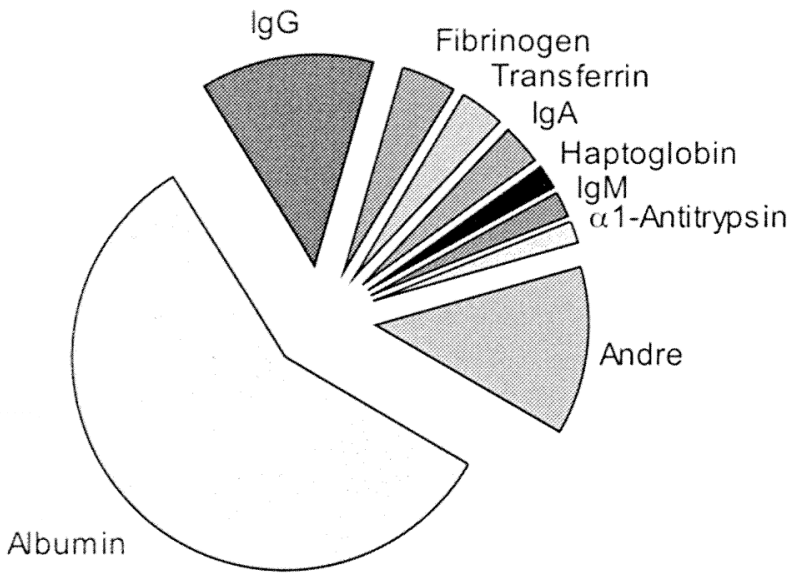

Figur 3. Åtte av de vanligste plasma-proteinene utgjør $>90 \%$ av det totale proteininnholdet i plasma. Det er i kategorien "Andre" at man forventer å finne nye sykdomsspesifikke biomarkører. For å øke mulighetene til å utforske denne gruppen av proteiner er det utviklet flere metoder for å fjerne mest mulig av de vanligste plasma-proteinene.

\section{Massespektrometri}

Utviklingen innen massespektrometri (MS) tyder på at det vil kunne bli det viktigste elementet innen proteomikk (16). Det kan brukes både til å oppdage nye proteiner eller mønstre av proteiner og peptider $\mathrm{i}$ en prøve eller til å kvantitere spesifikke proteiner.

Et massespektrometer består i prinsippet av tre forskjellige komponenter: en ionekilde, en masseanalysator og en ionedetektor $(16,17)$. Ved MS analyseres ioner i gassfase. Det er derfor nødvendig med metoder som kan overføre molekylene fra fast fase eller væske og over til ioniserte gasspartikler. Til dette formålet brukes vanligvis "matrix assisted laser desorption/ionisation" (MALDI) eller elektrospray-ionisering (ESI). Ved MALDI brukes laserpulser til å ionisere proteiner som er krystallisert på en organisk bærer, mens ESI ioniserer proteinene direkte fra en løsning som sprayes inn i massespektrometeret. I masse-analysatoren separeres de ioniserte proteinene og peptidene ut fra deres forhold mellom masse og ladning $(\mathrm{m} / \mathrm{z})$. Farten og retningen som ionene får mot en detektor kan styres ved hjelp av elektriske felt og magneter. "Time-of-flight" er en enkel masse-analysator hvor ionene separeres med hensyn til tiden det tar å komme gjennom et rør frem til detektoren. Flytiden er direkte relatert til m/z, og dermed kan massen til ionet beregnes forutsatt at ladningen ( $\mathrm{z}$ ) er kjent. Andre masse-analysatorer er ionefeller, kvadrupoler og ione-syklotroner som benytter Fourier-transformasjonsresonans (FTICR). Alle har forskjellige egenskaper med hensyn til oppløsning, nøyaktighet og om de kan gi informasjon om aminosyresekvensen. I tillegg er det mulig å koble sammen flere masse-analysatorer i samme instrument. Utviklingen av nye masse-analysatorer har de siste årene $i$ stor grad blitt drevet av behovet for å utvikle nye metoder for å kunne sekvensere genomet, men er nå blitt den viktigste drivkraften for å få til en effektiv karakterisering av proteomet.

MALDI kobles ofte sammen med TOF for å karakterisere proteiner som er separert ved hjelp av todimensjonal gelelektroforese og deretter skåret ut av gelen (18). I forkant av MS-undersøkelsen kuttes proteinet opp i peptider med en protease, for eksempel trypsin, som kutter mellom bestemte aminosyrer. Massen til peptid-fragmentene analyseres ved hjelp av MALDI-TOF-MS. Mønsteret sammenlignes i en database med de teoretisk mulige peptidfragmenter som behandling med den samme proteasen kan tenkes å gi. "Surface-enhanced laser desorption ionisation" (SELDI)-TOF-MS er en variant av MALDI hvor det er mulig å forandre på egenskapene til overflaten som prøven appliseres på etter behov (19). Dermed kan kompleksiteten i prøven reduseres ved å bruke overflater med høy affinitet for proteiner med bestemte egenskaper som for eksempel hydrofobisitet eller binding til bestemte antistoffer.

Når MS brukes for å identifisere nye proteiner ved en bestemt sykdom, er det ønskelig å kunne undersøke flere tusen proteiner samtidig i en komplekst sammensatt biologisk prøve. Valget av separasjonsmetode er avhengig av hvilke spørsmål som stilles og hvilket deteksjonsnivå som kreves. Ved den såkalte "bottomup"-tilnærmingen fordøyes sammensatte proteinblandinger enzymatisk før de fraksjoneres kromatografisk og undersøkes massespektrometrisk for å identifisere så mange peptid-fragmenter som mulig (20). Man finner som regel et svært begrenset antall peptider per protein, men det er ofte nok til å identifisere proteinet som var opphavet til peptidet. Metoden er egnet for automatisering og analysering av et stort antall prøver. Multidimensjonal protein-identifiseringsteknologi (MudPIT), også omtalt som "shotgun proteomics" betegner en automatisert "bottom-up"-prosess hvor proteinene separeres med flertrinns væskekromatografi (LC) og deretter analyseres ved hjelp av tandem MS (21). Med MudPIT var det mulig å identifisere nesten 1500 forskjellige proteiner $i$ et gjærcellelysat $i$ ett enkelt eksperiment (22). Den andre tilnærmingen betegnes som en "top-down"-prosess hvor det benyttes intakte proteiner og åpner for muligheten til å analysere forskjellige post-translasjonelle modifikasjoner og isoformer (23). Dette er i motsetning til MudPIT en tidkrevende analyse av ett og ett protein.

MS kan også brukes til å kvantitere proteiner forutsatt at det er tilgjengelig en merket intern standard. Det er vanligst å merke de interne standardene med stabile isotoper som ${ }^{2} \mathrm{H},{ }^{13} \mathrm{C},{ }^{15} \mathrm{~N}$ og ${ }^{18} \mathrm{O}$. MS kan skille mellom forskjeller i molekylvekt hos standard og det samme proteinet i prøven. Konsentrasjonen av proteinet i prøven kan dermed beregnes ved å se på forholdet mellom intensiteten i signalet generert av den interne standarden sammenlignet med det tilsvarende peptidet fra prøven. Små peptider merket med isotoper kan syntetiseres og brukes som standarder. Peptidene designes i forhold til hvilke peptider man forventer å finne for 
eksempel etter trypsinbehandling av prøven. Med denne teknikken var det mulig å kvantitere med en akseptabel variasjonskoeffisient 47 forskjellige plasmaproteiner fra samme prøve samtidig (24). Analyttene varierte $\mathrm{i}$ konsentrasjon fra $40 \mathrm{~g} / 1$ for albumin til 0,7 $\mathrm{mg} / \mathrm{l}$ for L-selectin. Forutsatt at det er mulig å lage gode interne standarder, er det spekulert $i$ at MS-baserte metoder kan gjøre det mulig å kvantitere flere hundre proteiner i samme prøve samtidig.

I fremstillingen av serum får blodet koagulere før prøven sentrifugeres og skilles fra blodlegemene. Dette fjerner fibrinogenet i prøven, men også en rekke andre proteiner, som for eksempel protrombin. Omvendt finner man i serum mange små proteiner (peptider) som ikke er i plasma. Gode pre-analytiske betingelser er en forutsetning for å få meningsfylte resultater i studier av peptidomet.

Peptidene i serum er som regel nedbrytningsprodukter fra større sirkulerende proteiner, for eksempel koagulasjonsfaktorer, eller fra nedbrytning av celler og vev. Påvisning av dette "degradomet", proteinnedbrytningsproduktene i prøven, er stort sett tolket som uttrykk for at prøven er ødelagt (25). Imidlertid har en studie nylig vist at sammensetningen av degradomet tvert imot kan indikere at det pågår bestemte sykdomsprosesser $(26,27)$. Kvantitering av spesifikke nedbrytningsprodukter som D-dimer i diagnostikk av trombose og N- og C-terminale telopeptider ved økt bennedbrytning er velkjente. Det nye er at et bestemt mønster eller signatur av drøyt 50 peptider i en blodprøve kan brukes til å skille mellom kreftpasienter og kontroller og til å skille mellom forskjellige kreftformer (prostata-, blære- og brystkreft) (27). Mønsteret kunne detekteres i serum, men ikke i plasma. Det spekuleres derfor i om de forskjellige kreftformene har ulik effekt på de proteinnedbrytende (proteolytiske) enzymene som aktiveres i forbindelse med koagulering.

I sirkulasjonen vil små peptider raskt fjernes i nyrene. Et alternativ til å undersøke degraderte proteiner $\mathrm{i}$ serum er derfor å se på mønsteret av peptider som utskilles i urinen (28). Urin-proteomet er spesielt velegnet for å finne biomarkører forbundet med sykdommer i urinveiene. Ved 2D-PAGE-fraksjonering er det påvist ca. 1400 distinkte punkter. Av disse lot $420 \mathrm{seg}$ identifisere massespektrometrisk og resulterte i påvisningen av 150 forskjellige proteiner (26).

Den store internasjonale interessen for å identifisere nye biomarkører i plasma kommer blant annet til uttrykk ved at Human Proteome Organization (HUPO) har etablert et Plasma Proteome Project (PPP) (29). PPP skal blant annet lage retningslinjer og anbefalinger for hvordan blodprøver tas, prosesseres og oppbevares. I tillegg ønskes det å standardisere mest mulig de analytiske prosedyrene som brukes for å påvise og identifisere proteinene. Hensikten er å få mest mulig direkte sammenlignbare resultater mellom de forskjellige forskningssentra. Sammensetningen av det humane plasma-proteom har en normal biologisk variasjon avhengig av forhold som alder, kjønn, menstruasjonssyklus, graviditet, prøvetidspunkt, måltider, stress og fysisk aktivitet. Disse faktorene må det tas hensyn til når det planlegges studier for å identifisere endringer $\mathrm{i}$ proteinsammensetning forbundet med sykdommer eller respons på behandling.

\section{REFERANSER}

1. Forsman RW. The value of the laboratory professional in the continuum of care. Clin Leadersh Manag Rev 2002; 16 (6): 370-3.

2. Anderson NL, Anderson NG. The human plasma proteome: history, character, and diagnostic prospects. Mol Cell Proteomics 2002; 1 (11): 845-67.

3. Thadikkaran L, Siegenthaler MA, Crettaz D, et al. Recent advances in blood-related proteomics. Proteomics 2005; 5 (12): 3019-34.

4. A J, Trygg J, Gullberg J, et al. Extraction and GC/MS analysis of the human blood plasma metabolome. Anal Chem 2005; 77 (24): 8086-94.

5. Ping P, Vondriska TM, Creighton CJ, et al. A functional annotation of subproteomes in human plasma. Proteomics 2005; 5 (13): 3506-19.

6. Anderson NL, Polanski M, Pieper R, et al. The human plasma proteome: a nonredundant list developed by combination of four separate sources. Mol Cell Proteomics 2004; 3 (4): 311-26.

7. Alpert JS, Thygesen K, Antman E, Bassand JP. Myocardial infarction redefined - a consensus document of The Joint European Society of Cardiology/American College of Cardiology Committee for the redefinition of myocardial infarction. J Am Coll Cardiol 2000; 36 (3): 959-69.

8. Anderson NG. Computer interfaced fast analyzers. Science 1969; 166 (903): 317-24.

9. Spencer CA, LoPresti JS, Fatemi S, Nicoloff JT. Detection of residual and recurrent differentiated thyroid carcinoma by serum thyroglobulin measurement. Thyroid 1999; 9 (5): 435-41.

10. Haab BB. Antibody arrays in cancer research. Mol Cell Proteomics 2005; 4 (4): 377-83.

11. Schweitzer B, Roberts S, Grimwade B, et al. Multiplexed protein profiling on microarrays by rolling-circle amplification. Nat Biotechnol 2002; 20 (4): 359-65. 
12. Klose J. Protein mapping by combined isoelectric focusing and electrophoresis of mouse tissues. A novel approach to testing for induced point mutations in mammals. Humangenetik 1975; 26 (3): 231-43.

13. Jellum E, Thorsrud AK. Clinical applications of two-dimensional electrophoresis. Clin Chem $1982 ; 28$ (4 Pt 2): 876-83.

14. Wang YY, Cheng P, Chan DW. A simple affinity spin tube filter method for removing high-abundant common proteins or enriching low-abundant biomarkers for serum proteomic analysis. Proteomics 2003; 3 (3): 243-8.

15. Bjorhall K, Miliotis T, Davidsson P. Comparison of different depletion strategies for improved resolution in proteomic analysis of human serum samples. Proteomics 2005; 5 (1): 307-17.

16. Guerrera IC, Kleiner O. Application of mass spectrometry in proteomics. Biosci Rep 2005; 25 (1-2): 71-93.

17. Yates JR, $3^{\text {rd }}$. Mass spectral analysis in proteomics. Annu Rev Biophys Biomol Struct 2004; 33: 297-316.

18. Pusch W, Kostrzewa M. Application of MALDI-TOF mass spectrometry in screening and diagnostic research. Curr Pharm Des 2005; 11 (20): 2577-91.

19. Seibert V, Wiesner A, Buschmann T, Meuer J. Surface-enhanced laser desorption ionization time-of-flight mass spectrometry (SELDI TOF-MS) and ProteinChip technology in proteomics research. Pathol Res Pract 2004; 200 (2): 83-94.

20. Listgarten J, Emili A. Statistical and computational methods for comparative proteomic profiling using liquid chromatography-tandem mass spectrometry. Mol Cell Proteomics 2005; 4 (4): 419-34.

21. McDonald WH, Yates JR, $3^{\text {rd }}$. Shotgun proteomics and biomarker discovery. Dis Markers 2002; 18 (2): 99 105.

22. Washburn MP, Wolters D, Yates JR, $3^{\text {rd }}$. Large-scale analysis of the yeast proteome by multidimensional protein identification technology. Nat Biotechnol 2001; 19 (3): 242-7.

23. Kelleher NL. Top-down proteomics. Anal Chem 2004; 76 (11): 197A-203A.

24. Anderson NL, Hunter CL. Quantitative mass spectrometric MRM assays for major plasma proteins. Mol Cell Proteomics, In press.

25. Liotta LA, Petricoin EF. Serum peptidome for cancer detection: spinning biologic trash into diagnostic gold. $J$ Clin Invest 2006; 116 (1): 26-30.

26. Hwang IK, Park SM, Kim SY, Lee ST. A proteomic approach to identify substrates of matrix metalloproteinase-14 in human plasma. Biochim Biophys Acta 2004; 1702 (1): 79-87.

27. Villanueva J, Shaffer DR, Philip J, et al. Differential exoprotease activities confer tumor-specific serum peptidome patterns. J Clin Invest 2006; 116 (1): 271-84.

28. Veenstra TD, Conrads TP, Hood BL, et al. Biomarkers: mining the biofluid proteome. Mol Cell Proteomics 2005; 4 (4): 409-18.

29. Omenn GS, States DJ, Adamski M, et al. Overview of the HUPO Plasma Proteome Project: results from the pilot phase with 35 collaborating laboratories and multiple analytical groups, generating a core dataset of 3020 proteins and a publicly-available database. Proteomics 2005; 5 (13): 3226-45. 